\title{
Tantra as Experimental Science in the Works of John Woodroffe
}

\begin{abstract}
John Woodroffe (1865-1936) can be counted among the most influential authors on Indian religious traditions in the twentieth century. He is credited with almost single-handedly founding the academic study of Tantra, for which he served as a main reference well into the 1970s. Up to that point, it is practically impossible to divide his influence between esoteric and academic audiences - in fact, borders between them were almost non-existent. Woodroffe collaborated and exchanged thoughts with scholars such as Sylvain Lévi, Paul Masson-Oursel, Moriz Winternitz, or Walter Evans-Wentz. His works exerted a significant influence on, among many others, Heinrich Zimmer, Jakob Wilhelm Hauer, Mircea Eliade, Carl Gustav Jung, Agehananda Bharati or Lilian Silburn, as they did on a wide range of esotericists such as Julius Evola. In this light, it is remarkable that Woodroffe did not only distance himself from missionary and orientalist approaches to Tantra, but he also identified Tantra with Catholicism and occultism, introducing a universalist, traditionalist perspective.
\end{abstract}

This was not simply a "Western" perspective, since Woodroffe echoed Bengali intellectuals who praised Tantra as the most appropriate and authentic religious tradition of India. In doing so, they stressed the rational, empirical, scientific nature of Tantra that was allegedly based on practical spiritual experience. As Woodroffe would later do, they identified the practice of Tantra with New Thought, spiritualism, and occultism - sciences that were only re-discovering the ancient truths that had always formed an integral part of "Tantrik occultism." This chapter situates this claim within the context of global debates about modernity and religion, demonstrating how scholarly approaches to religion did not only parallel, but were inherently intertwined with, occultist discourses.

\section{Introduction}

The publications of John Woodroffe, some of which appeared under the pseudonym Arthur Avalon, are of major importance for the modern reception of Tantra. They remain a central resource for present-day esoteric and non-academic practitioners and were widely regarded as an authority within the academic study of 
religions until the 1970s. In fact, Woodroffe is viewed as the father of Tantric Studies, and by extension of the practice of Tantra in the West. ${ }^{1}$ Even if his writings were criticised for their shortcomings, there is no doubt that they were instrumental for highlighting the importance of Tantra for Indian religious history and establishing it as an accepted subject of serious research. ${ }^{2}$ That Woodroffe came to play such an important role is not least due to his remarkable life, over three decades of which he spent in colonial Bengal. A child of converts to Catholicism, he received an education at an unconventional liberal Catholic school and obtained a Bachelor in Law after studying in Oxford from 1884-1888. From 1890, he served as a barrister at the High Court of Calcutta and taught as the Tagore Law Professor of Calcutta University. In 1904, he was promoted to the judiciary and served at the High Court until 1922, when he returned to England and taught Indian Law at Oxford University until 1930. He retired to Southern France and lived in Beausoleil, near Monaco, until his death.

This glimpse into Woodroffe's life already indicates that his activities can serve as an outstanding example of a global religious history. What Woodroffe presented to his many readers as "Tantra" was the outcome of a complex tangle of exchanges between different South Asian (especially Bengali) intellectuals, Western orientalists, missionaries, esotericists, and other participants in the struggle about the meaning of, and the relationship between, religion, science, philosophy, and national identity. It is well known that it was not Woodroffe alone who stood behind Arthur Avalon, but that this name represented a collaboration between him and several learned Indians, a fact which he openly admitted himself. ${ }^{3}$ Thanks to a careful study by Kathleen Taylor, we know that Woodroffe's chief partner was Ațal Bihāri Ghoș, ${ }^{4}$ one of several scholars without whose knowledge

\footnotetext{
1 David Gordon White, Kiss of the Yogini: 'Tantric Sex' in its South Asian Contexts (Chicago: University of Chicago Press, 2003), xi; Hugh B. Urban, Tantra: Sex, Secrecy Politics, and Power in the Study of Religions (Berkeley: University of California Press, 2003), 136; André Padoux, The Hindu Tantric World: An Overview (Chicago: University of Chicago Press, 2017), 6.

2 See, e.g., Chintaharan Chakravarti, Tantras: Studies on their Religion and Literature (Calcutta: Punthi Pustak, 1963), v; Sanjukta Gupta, Dirk Jan Hoens, and Teun Goudriaan, Hindu Tantrism (Leiden: Brill, 1979), 4; or the references in Sures Chandra Banerji, Tantra in Bengal: A Study in its Origin, Development, and Influence, 2nd ed. (New Delhi: Manohar Publications, 1992).

3 E.g., in John Woodroffe, Shakti and Shakta: Essays and Addresses on the Shakta Tantrashastra (London: Luzac \& Co., 1918), i.

4 The names of historical actors and the titles of publications will be romanised in this article according to the Bangla Academy standard. Exempt are place names and some Sanskrit terms that have entered the English language.
} 
and linguistic skills the Woodroffe/Avalon publications would not have been possible. ${ }^{5}$ This demonstrates the complexity of the exchanges behind these publications, which reflected a controversial discourse about Tantra that had gained new momentum in Bengal towards the end of the nineteenth century. These controversies had emerged since the beginning of the nineteenth century within a global context of exchanges between Westerners and Indians.

What we find in the writings of Woodroffe/Avalon is a "reformed" Tantra, in the words of Hugh Urban and David Gordon White, whose proponents sought to actively engage with contemporary learned debates. In contrast to the accounts of missionaries, orientalists, and colonial administrators, who had regarded Tantra as superstition and idolatry at best, if not as outright sexual perversion and black magic, these "reformers" presented a form of "deodorized," "cosmeticized," or "semanticized" Tantra whose more transgressive or controversial elements were depicted in a highly philosophised fashion. ${ }^{6}$ As Sanjukta Gupta, Dirk Jan Hoens, and Teun Goudriaan have pointed out, Woodroffe/Avalon's depiction of Tantra was "motivated by the desire to propagate [the specific current of] Sākta Tantrism and to apologize against orthodox Hindus and Victorian missionaries." While these assessments are certainly true, there is a dimension to this depiction of Tantra that deserves further scrutiny. Woodroffe/Avalon, and the numerous Bengali intellectuals who propagated similar ideas, did not regard themselves as reformists. Quite the contrary: they were staunchly opposed to so-called "reformers" and propagated, time and again, the revival and defence of a traditional "orthodoxy" that had allegedly been corrupted by foreign education and the degeneration of the Indian socio-religious fabric.

This notion put the Bengali discourse about Tantra at the heart of the struggle for religious and national identity in colonial India. Tantra would invigorate the oppressed Hindus, not only by reviving their authentic religious tradition, but also by proving the scientific and rational character of this tradition. This would

5 In what follows, "Woodroffe/Avalon" will be used to refer to the writings published under both names. Woodroffe also started publishing under his given name, while "Arthur Avalon" continued to be used for the collaborative Tantrik Texts, a series of editions. Some writings that were first published under the name of Arthur Avalon were later published under the name of Woodroffe.

6 Urban, Tantra, 135-137; David Gordon White, "Introduction," in Tantra in Practice, ed. David Gordon White (Princeton: Princeton University Press, 2000), 17; Alexis Sanderson, "Meaning in Tantric Ritual," in Essais sur le Rituel III: Colloque du Centenaire de la Section des Sciences religieuses de l'École Pratique des Hautes Études, ed. Anne-Marie Blondeau and Kristofer Schipper (Louvain-Paris: Peeters, 1995), 87; cf. White, Kiss, xii.

7 Gupta, Hoens, and Goudriaan, Hindu Tantrism, 4. 
not only serve as an antidote to colonial oppression, but also to the materialistic and sectarian ailments of modernity as a whole. This "scientific spirituality" had a decidedly universalistic thrust, which implied that it was the West that should learn from India, rather than vice versa. In what follows, two aspects of these ideas will be discussed: this is, first, the arguably very modern focus on science and rationality that seems to contradict the fierce anti-modernism of its proponents. And second, the proclaimed universalism of a tradition that was presented as the authentic core of Hindu identity. These two points are of special interest because they provided structural analogies and actual points of contact with both "Western esotericism" and contemporary orientalist scholarship. It will be argued that this is among the main reasons why the borders between esoteric and academic recipients of Woodroffe's/Avalon's writings were fluid and often non-existent well into the second half of the twentieth century.

\section{The Exchange between Bengali Intellectuals and Theosophists}

As indicated above, the activities of Woodroffe/Avalon emerged from a Bengali discourse that had gained momentum towards the end of the nineteenth century. In that respect, it is significant that the first two major books published by Arthur Avalon were The Great Liberation (1913) and the Principles of Tantra (1914). ${ }^{8}$ Both titles were later published under Woodroffe's name and saw many editions up to the present day. The Great Liberation was a translation of the Mahānirvānatantra, a highly influential text that was probably composed by a Bengali pandit at the end of the eighteenth century. ${ }^{9}$ While the provenance of the text is still unclear, it was evidently popular among reform-oriented Hindus who had received a Western education and thus played a central role for nineteenth-century understandings of Tantra. Avalon wrote a lengthy introduction to the translation, which was later published as

8 The years 1913 and 1914 also saw the beginning of the Tantrik Texts series. Edited by Tārānātha Vidyāratna, the three Sanskrit texts that were published then were the Tantrābhidhāna, the ȘatCakra-Nirūpaṇa, and the Prapañcasāra. This selection is very significant but cannot be further discussed in the present context.

9 John D.M. Derrett, “A Juridical Fabrication of Early British India: The Mahānirvāṇa-Tantra,” Zeitschrift für Rechtswissenschaft 69, no. 2 (1968); Teun Goudriaan and Sanjukta Gupta, Hindu Tantric and Sākta Literature (Wiesbaden: Harrassowitz, 1981), 98-99; Banerji, Tantra in Bengal, 104-111; Urban, Tantra, 64-70. 
Introduction to Tantra Shastra and, despite its flaws, is still appreciated by scholars as a remarkably nuanced and well-informed pioneering piece. The two volumes of Principles of Tantra were a translation of the Tantratattva, a text by the charismatic guru Śivacandra Vidyārṇava (1861-1914) that had been published in Bengali in 1893. The Principles of Tantra were a collaborative effort between Arthur Avalon, who wrote the Preface and Introduction to the first volume, and two Bengali scholars: Jñānendralāl Majumdār, who had been mainly responsible for the translation, and Baradā Kānta Majumdār, who wrote the Introduction to the second volume. The lives and works of these learned Bengalis are still largely unknown. In the present context, the discussion will have to be limited to the question of how they presented Tantra as an experimental, rational science.

The works of Arthur Avalon were the climax of a long effort by Bengali intellectuals to reshape the perception of Tantra and establish it as the true, esoteric core of Hindu religion - and, by extension, of religion in general. It is highly remarkable that the effort to communicate these ideas in English to an international readership was initiated in the leading Theosophical periodical, The Theosophist. Beginning in its very first volume of 1880, we can observe a lively exchange about Tantra between Indian, European, and US-American authors that would last until 1891. It was only in 1913 that the topic was taken up again within the pages of The Theosophist: by a "Hymn to Durga (from the Siddheshvara Tantra)," penned by none other than Arthur Avalon. This is no coincidence, because the group of authors from the 1880 s represented the very same milieu that would later inform Woodroffe.

As Karl Baier has observed with regard to discussions about Yogic practices, the discussion of Tantra in The Theosophist was initiated by an inquiry from a "Truth Seeker" in January $1880 .^{10}$ This "European Theosophist" was fascinated by a series of papers in the Dublin University Magazine from 1853 and 1854, which discussed Yogic practices. Those were linked to a "Power" that was explained as the Kundalini, and that was supposedly described in "that most mystic of all mystic books, the Dnyaneshvari."11 The Truth Seeker compared

10 This was first observed by Karl Baier, Meditation und Moderne: Zur Genese eines Kernbereichs moderner Spiritualität in der Wechselwirkung zwischen Westeuropa, Nordamerika und Asien, vol. 1 (Würzburg: Königshausen \& Neumann, 2009), 324-329; cf. Karl Baier, "Mesmeric Yoga and the Development of Meditation within the Theosophical Society," Theosophical History 16, no. 3-4 (2012) and Karl Baier, "Theosophical Orientalism and the Structures of Intercultural Transfer: Annotations on the Appropriation of the Cakras in Early Theosophy," in Theosophical Appropriations: Esotericism, Kabbalah, and the Transformation of Traditions, ed. Julie Chajes and Boaz Huss (Beer Sheva: Ben-Gurion University of the Negev Press, 2016).

11 This is the Jñanneśvarī, a famous thirteenth-century Marathi rendering of the Bhagavadgitā. 
these practices to those of the Oupnek'hat ${ }^{12}$ as well as to the mystical experience described in Thomas Vaughan's Anima Magica Abscondita. He wondered if "any of the correspondents" of the Theosophist could provide more information, and if Dayānanda Saraswatī "would give the world a translation of this work, and also of Patanjali's Yoga Sastra ... " He concluded: "We Western Theosophists earnestly desire information as to all the best modes of soulemancipation and will-culture, and turn to the East for Light."13

In a note in the February issue of The Theosophist, "a Bengali friend" responded that Swāmī Dayānanda "was in error when he condemned the Tantras. He has evidently seen the black Tantra and rejected all in disgust. But the Tantras alone contain all that has been discovered regarding the mysteries of our nature. They contain more than the Veds, Patanjali, Sankhya and other ancient works on Yoga philosophy." Since they were in Bengali character, they were inaccessible to English audiences, which is why the author urged those in Bengal who "care enough for truth and science" to provide English translations. ${ }^{14}$ The Bengali friend's remark about the "error" of Dayānanda reflected an enduring Indian debate. Swāmī Dayānanda Saraswatī (1824-1883) had founded the reformoriented Ārya Samāj in 1875 in Mumbai (then Bombay) and was briefly affiliated with the Theosophical Society, which had even renamed itself "The Theosophical Society of the Arya Samaj of India” in May 1877. Dayānanda was a harsh critic of Tantra, which he regarded as a superstitious and obscene degeneration of Indian tradition that was opposed to the Vedas. Reflecting the stereotypes of Christian missionary literature - and using the language of Protestant polemics when he referred to "the trickery of these stupid popes" - he did indeed regard the Tantras as a vicious genre of "disgusting literature." 15 Similarly, many followers of the Brāhma Samāj, founded 1828 in Kolkata (then Calcutta), had looked down upon Tantra, although the role of Tantra for their society was more ambivalent, as will be seen below. In his note, the Bengali friend took a stance that was diametrically opposed to such polemics. Despite its briefness, it contained two central arguments that were often leveled against attacks on Tantra: first, that it was not only part of the Vedic tradition, but that it even "contain[ed] more than the Veds"; second, that one must differentiate between "black" and "white" Tantra. The latter aspect introduced Tantra into the "Western esoteric"

12 The first Latin translation by Abraham Hyacinthe Anquetil-Duperron (1801/02) of the Persian rendering of the Upanishads (1657).

13 Truth Seeker, "Yoga Philosophy," The Theosophist 1, no. 4 (1880): 87.

14 The Theosophist 1, no. 5 (1880): 113.

15 Urban, Tantra, 60. 
discourse on black versus white magic. While Western Theosophists, so far informed by writings such as those by orientalists, missionaries, or reformers like Dayānanda, had regarded Tantra as black magic plain and simple, they now came under the influence of a learned discourse that attempted to elevate Tantra in its "white" variety to the status of "Indian esotericism" in its pu-rest and noblest form. Some decades later, this was the view that would be popula-rized and established as the standard by Woodroffe/Avalon.

\section{The Indian Occultism of Baradā Kānta Majumdār}

The link between these encounters in the Theosophist and the publications of Woodroffe/Avalon could not be more direct: the first Bengali scholar who reacted to the requests was Baradā Kānta Majumdār, the afore-mentioned collaborator on Principles of Tantra. He wrote a series of articles about "Tantric Philosophy" and "A Glimpse of Tantric Occultism" from April to October 1880. Therein he explained that the Tantras were the most comprehensive and profound compendium of knowledge, but that they were often misunderstood and denounced because of their esoteric character: "The Tantriks like the Freemasons and Rosicrucians studiously hide their books and secrets from the outside world." By explaining some of its esoteric contents, Majumdār wished to "disabuse the minds of the Tantra-haters of their misconception about this very instructive and interesting branch of Hindu literature."16 For this, Majumdār's authority was the Mahānirvānatantra, which, as the reader might recall, was later published by Arthur Avalon as The Great Liberation. Majumdār's references to the Mahānirvannatantra are fascinating from several perspectives; in the present context, his focus on kundalini and śakti are especially relevant since they highlight his concern to prove the authority of Tantra on the basis of recent scientific findings. He argued, for instance: "Modern science also teaches us that heat, light, electricity, magnetism, \&c., are but the modifications of one great force.” These forces, Majumdār explained, are but different manifestations of the Kundalini and thus only aspects of one all-pervading unity. ${ }^{17}$ Majumdār's implication here is that modern science was only starting to re-discover what ancient Tantric doctrines had always taught, and it is highly relevant that he

16 Baradā Kānta Majumdār, “Tantric Philosophy,” The Theosophist 1, no. 7 (1880): 173.

17 Majumdār, "Tantric Philosophy," 173. 
referred to this, in his next articles, as "Tantric Occultism.” There he argues for the inferiority of modern science in comparison to the teachings of Tantra:

There is a point beyond which experimental science cannot go; and that is the point which divides the empire of what is called matter from the empire of force. Certainly the physicist is acquainted with the nature and laws of certain forces, or more correctly, certain modifications of some mysterious force, but beyond this every thing is in darkness. To the modern scientist the land of mystery is sealed with seven seals. His instruments and machines, his scalpel and retort serve him ill to solve the grand problem of existence. Is there no hope then? Are there no means by which the occultism of nature may be revealed to man? Aryan philosophy says there are. ${ }^{18}$

As familiar as this line of argumentation will be to experts on esotericism, the relevant fact here is that a Bengali author chose to adopt it for his defence of Tantra. To put it differently: it is highly remarkable that this defence of Tantra was first taken up within the pages of an esoteric journal, using an esoteric language, and comparing Tantric practices to those of contemporary "Western esotericism" - going as far as to label the very subject of the argument "Tantric Occultism.” Some historical explanations for this shall be indicated here: for instance, Tantra had been regarded as "black magic" by missionaries and Indian reformers from an early point on, a fact that, as has been seen, resurfaced in The Theosophist and enabled Western esotericists and Indian intellectuals to engage in a conversation about the legitimacy of magic that had been essential to the emergence of modern esotericism. In this context, notions of an allpervading force were commonplace among Western esotericists since the popularity of Mesmerism and spiritualism; just like esotericists in the West, Majumdār linked these theories to contemporary theories of matter and energy, to which his notion of śakti was highly compatible. Third, his emphasis on "Aryan philosophy" leads back to the orientalist notion of a religious and cultural origin in "the East" that was essential to the emergence of Theosophy and, as is well known, responsible for the activities of the Theosophical Society in India in the first place.

In short, Majumdār actively engaged with the Western Theosophists' "earnest desire for information" and their eagerness to "turn to the East for Light," to use the words of the Truth Seeker. Majumdār clearly regarded the Theosophists as allies against missionaries or reformers such as those of the Ārya Samāj or the Brāhma Samāj and their joint attack on superstition, idolatry, and black magic.

18 Baradā Kānta Majumdār, "A Glimpse of Tantrik Occultism 1,” The Theosophist 1, no. 10 (1880): 244. 
He joined the Theosophical Society on 26 July 1880, while writing his "Glimpse of Tantric Occultism." ${ }^{19}$ He was one of the contributors to the well-noted Guide to Theosophy from 1887, edited by Tukaram Tatya (1836-1898) who had joined the Theosophical Society on 2 May 1880. Majumdār's entry about “The Occult Sciences" underlines his familiarity, and will to engage, with Western occultism. Following an epigraph by Paracelsus, Majumdār denounced the "sectarian narrowness and blind prejudice" that was noticeable "in this boastful nineteenth century of intellectual scientists and philosophers." Praising the wisdom of the Indian Yogis, he maintained that "[t]he occult sciences of India are the monuments of her ancient greatness," to which, it is implied; those who have received "fair education in Western science and philosophy" have to look for answers. He defined these occult sciences as follows:

I beg in the first place to promise that they contain nothing in them that may be considered supernatural. On the other hand all the occult sciences are based upon natural laws and forces and are the result of investigation and experiment. The end and aim of these sciences is to discover and develop certain powers in man, which, for want of proper culture, lie dormant and useless, but which, if properly brought to action, can truly give him the name of the 'Lord of creation. ${ }^{20}$

Majumdār drew explicit comparisons with the history of "Western esotericism" when he maintained that, in their efforts to explain the subtle forces of nature, the investigations of the Indian ascetics paralleled those of Franz Anton Mesmer (1734-1815), Karl von Reichenbach (1788-1869), and Jules Denis du Potet de Sennevoy (1796-1881). After providing a long quote from Ebenezer Sibly (1751-1799), an early follower of Mesmer's theories, Majumdār referred the curious reader "to the Tantrik works in Sanskrit and to the English works of Mr. Sebly [sic], Dr. Dee, \&c.” He concluded his entry with the following passage:

The science of mesmerism in all its branches has thrown a flood of light on Indian occultism, which may now be read and intelligently understood by any average reader who has but a slight knowledge of mesmerism. But Western mesmerism is yet in its infancy; and it is hoped that with the help of Indian occultism it will fast gain the position which other sciences now occupy. There is, however, one great distinction between Indian occultism and European mesmerism; viz., that while the latter depends upon secondary sources (subjects mesmerised) for the discovery of its truths, the former only treats of self mesmerisation. In the one case the operator has to rely upon the evidence of his patient, but

19 The second part of which was completed on 2 August 1880.

20 Baradā Kānta Majumdār, "The Occult Sciences," in A Guide to Theosophy, ed. Tukaram Tatya (Bombay: The Bombay Theosophical Publication Fund, 1887), 206. 
in the other the self-mesmerised philosopher observes phenomena by the aid of himself alone, in an ordinary conscious state. ${ }^{21}$

Similar to the established modern sciences, Western Mesmerism was only beginning to discover and explain things that Indian occultism had long understood and practiced. Hence it was the Westerners who could benefit from Indian teachings, not the other way around. Majumdār's argument for the practical superiority of Indian occultism is remarkable in itself, although he seemed to be unaware of the fact that occultists, beginning with Eliphas Lévi (i.e., Alphonse-Louis Constant, 1810-1875), had long levelled the technique of "selfmagnetisation" against the supposedly inferior practitioners of Mesmerism and spiritualism. ${ }^{22}$ Be that as it may, the point here is that Majumdār is among the first Indian authors who entered a dialogue with Western occultists and developed the notion of Indian occultism with the tradition of Tantra at its core, employing a language and narrative that clearly (and, most likely, intentionally) paralleled "Western esoteric" discourse.

\section{Woodroffe/Avalon and "Western Esotericism"}

In light of this exchange, it is a significant but often overlooked fact that Arthur Avalon himself actively reached out to Theosophists when he entered the stage. Two translated hymns were published in The Theosophist in October 1913 and June 1914, as a result of the book Hymns to the Goddess, which was copublished in 1913 with "Ellen Avalon," Woodroffe's wife. In fact, Ellen was a member of the Theosophical Society and well acquainted with Annie Besant. ${ }^{23}$ John never became a member himself, but he published in journals such as the Theosophist, Theosophical Review, or Occult Review, and he frequently quoted from publications such as The Quest. He gave lectures to the Theosophical Society, and his books were published by Theosophical publishers such as Ganesh \& Co. in Chennai (then Madras).

21 Majumdār, "The Occult Sciences,” 209.

22 Julian Strube, Sozialismus, Katholizismus und Okkultismus im Frankreich des 19. Jahrhunderts: Die Genealogie der Schriften von Eliphas Lévi, Religionsgeschichtliche Versuche und Vorarbeiten (Berlin: De Gruyter, 2016), 529. The concept of self-magnetisation had also been proposed by Du Potet, among others.

23 Kathleen Taylor, Sir John Woodroffe, Tantra and Bengal: An Indian Soul in a European Body? (Richmond: Curzon, 2001), 44, 148. 
At the same time, he was critical of the Theosophical ideas that he frequently referred to, openly criticising, for instance, Charles Webster Leadbeater. ${ }^{24}$ Similarly, Baradā Kānta Majumdār pointed out what he regarded as Theosophical misconceptions of Indian concepts. ${ }^{25}$ This suggests that Woodroffe and his Indian collaborators were well aware of what the former called "substantial points of difference" between Theosophical writings and what was perceived as more authentic Indian teachings. However, Woodroffe was "aware that the Theosophical Society has no official doctrine," 26 and it is evident that he regarded Theosophists as dialogue partners in his efforts to spread knowledge about the value of Indian teachings. This appreciation is made explicit as early as in the first volume of Principles of Tantra, where it is pointed out that "[t]he spread of Theosophical ideas first renewed an interest in the teachings of India's great past, and an awakening national spirit has done the rest." ${ }^{27}$ The Indian-British team behind Arthur Avalon seems to have been well aware of the role of Theosophy as a platform of dialogue between India and the West, which is also expressed in a statement by Woodroffe in 1922: "The debt of Theosophy to India is well known as also (though in another sense) of India to Theosophy which re-called to the Indian the value of his cultural inheritance." 28

This echoes the sentiment of many Indian authors who, even if they might have been critical of Theosophical ideas and, as Dayānanda had done, eventually turned their back on them, recognized the platform that the Theosophical Society offered them. Through journals such as the Theosophist, a significant part of the Indian intelligentsia was enabled to communicate with an international readership that was highly sympathetic to their ideas. Theosophical publishers vigorously reached out to Indians to publish in English, provide translations, or edit vernacular sources that were previously inaccessible to most readers. Theosophical concepts exerted a significant influence on Indian intellectual discourse that becomes tangible in the ideas of thinkers as prominent as Mahatma Gandhi. ${ }^{29}$ Moreover, the Theosophical Society was an open arena for social reform and soon established itself as a recognizable force in

24 John Woodroffe, The Serpent Power: Being the Shat-Chakra-Nirupana and Paduka-Panchaka (Madras: Ganseh \& Co., 1924), 6-7, 12-15. Cf. Taylor, Woodroffe, 149.

25 E.g., in John Woodroffe, Principles of Tantra, vol. 2 (London: Luzac \& Co., 1914), xix.

26 Woodroffe, Serpent Power, 14-15.

27 John Woodroffe, Principles of Tantra, vol. 1 (London: Luzac \& Co., 1914), x.

28 John Woodroffe, The World as Power: Power as Life (Madras: Ganesh \& Co., 1922), xxi-xxii. 29 Michael Bergunder, "Experiments with Theosophical Truth: Gandhi, Esotericism, and Global Religious History," Journal of the American Academy of Religion 82 (2014). 
the socio-political landscape of India - a fact that culminated in Annie Besant's presidency of the Indian National Congress in $1917 .^{30}$

It is against this background that Woodroffe's/Avalon's engagement with Theosophy has to be viewed. Similar to their Western interlocutors, many Indian authors propagated religious universalism, rejected modern materialism and scepticism, and pointed to an idealised past whose secret wisdom had to be revived. The notion of "Indian occultism," with Tantra at its core, would play a central role in these debates. Given the fact that Majumdār would later collaborate with Arthur Avalon, it is not surprising that the same ideas would resurface, not only in the introductions and commentaries to The Great Liberation and the Principles of Tantra, but also in prominent works such as The Serpent Power or Shakti and Shakta (both 1918) that decisively informed a global academic and non-academic readership. In these writings, Indian occultism is presented as decidedly scientific, rational, and based on the empirical experience of a religious practice that is executed with the precision of a scientific experiment. In Shakti and Shakta, we read: "The Tantras both in India and Tibet are the expression of principles which are of universal application. The mere statement of religious truths avails not. What is necessary for all is a practical method of realization. This too the occultist needs."31 And, some pages later:

Over and above the fact that the Shastra [i.e., the doctrine of Tantra] is an historical fact, it possesses, in some respects, an intrinsic value which justifies its study. Thus it is the storehouse of Indian occultism. This occult side of the Tantras is of scientific importance, the more particularly having regard to the present revived interest in occultist study in the West. "New thought" as it is called and kindred movements are a form of Mantravidyā. Vashīkaraṇam is hypnotism, fascination. There is "Spiritualism" and "Powers" in the Tantras and so forth. ${ }^{32}$

30 Catherine L. Wessinger, Annie Besant and Progressive Messianism, Studies in Women and Religion (Lewiston: Mellen, 1988); Mark Bevir, "In Opposition to the Raj," History of Political Thought 19 (1998); Gauri Viswanathan, Outside the Fold: Conversion, Modernity, and Belief (Princeton: Princeton University Press, 1998), 177-207; Mark Bevir, "Theosophy as a Political Movement," in Gurus and Their Followers, ed. Antony Copley (Delhi: Oxford University Press, 2000); Peter van der Veer, Imperial Encounters: Religion and Modernity in India and Britain (Princeton: Princeton University Press, 2001), 55-82; Mark Bevir, "Theosophy and the Origins of the Indian National Congress," International Journal for Hindu Studies 7, no. 1/3 (2003); Isaac Lubelsky, Celestial India: Madame Blavatsky and the Birth of Indian Nationalism (Sheffield: Equinox, 2012).

31 John Woodroffe, Shakti and Shakta: Essays and Addresses on the Shakta Tantrashastra, 3rd ed. (Madras/London: Ganesh \& Co./Luzac \& Co., 1929), 62.

32 Woodroffe, Shakti and Shakta, 73-74. 
Like Majumdār and other Indian authors before him, Woodroffe emphasised that recent scientific findings would confirm the occult teachings of the Tantras, and just like them he saw esoteric movements at the vanguard of this scientific progress. At the same time, he made it clear that these discoveries were incomplete and infantile in comparison to what Indian sages had already been practising for millennia. This opens up a historical and socio-political dimension of Woodroffe's/Avalon's “Tantra Shastra” that actively sought confrontation with contemporary orientalist, missionary, and scientific opinions. Their failure, we read in Shakti and Shakta, was not only to reject Tantra, but also occultism in the West. Both being an expression of "principles which are of universal application," their acknowledgement would open up the path to a proper understanding of a universal "orthodoxy":

Those familiar with the Western presentment of similar matters will more readily understand than others who, like the Orientalist and Missionary, as a rule know nothing of occultism and regard it as superstition. For this reason their presentment of Indian teaching is so often ignorant and absurd. The occultist, however, will understand the Indian doctrine. . . 33

In the second edition of The Serpent Power, this remark is echoed emphatically: "It is because the Orientalist and missionary know nothing of occultism, and regard it as superstition, that their presentment of Indian teaching is so often ignorant and absurd." 34 In other words, only someone who is familiar with occultism will be able to comprehend the wisdom of India. It would be an overstatement to say that Woodroffe was an occultist; rather, the point is that his approach to Tantra was informed by ideas that had been expressed by learned Bengalis decades earlier in exchange with Theosophists. As Kathleen Taylor has shown, Woodroffe actively engaged with contemporary theories from diverse fields such as physics, psychology, Theosophy, or New Thought, without being an adherent of any particular movement. ${ }^{35}$ It must be stressed, however, that this was hardly an innovation for the discourse about Tantra that had been going on among Indian intellectuals in the preceding decades.

33 Woodroffe, Shakti and Shakta, 464.

34 Woodroffe, Serpent Power, 86.

35 E.g., Taylor, Woodroffe, 194-202. 


\section{The "Orthodoxy" of Śivacandra Vidyārṇava}

A nodal point of the ambitions to defend Tantra against its critics and establish it as an Indian "orthodoxy" are the activities of the afore-mentioned Śivacandra Vidyārṇava. Several of Woodroffe's main collaborators were disciples of this remarkable Tantric guru, and it appears that Woodroffe had received Tantric initiation (dìkṣa $)$ from him. ${ }^{36}$ Sivacandra Bhațtācārya was born in the village Kumarkhali in the Nadiya district, today part of Bangladesh. ${ }^{37}$ The region was populated by several outstanding figures of Indian religious, artistic, and political life, including Lālan Fakir, with whom Śivacandra was apparently acquainted. Śivacandra's family proudly looked back on a long tradition of renowned tāntrikas, and his descendants are still active in Haora, taking care of the temple of Śivacandra's ișta-devī Sarvamangalā, his preferred Goddess of worship. ${ }^{38}$ From an early point on, his life reflects a struggle against the influence of Western education and the fading of Indian tradition. Reportedly, his father had been outraged when his son had to read the story of Valentine Duval as a pupil and decided not to send him to school from that day on. ${ }^{39}$ Later, when Śivacandra was offered to study at the Sanskrit College, his father and grandfather denied him the permission because of the influence of English at the College. ${ }^{40}$ Nevertheless, Śivacandra received a comprehensive Sanskritic education. Having completed the Vidyāsāgar exam, he rejected the title because of his respect for the renowned scholar and editor Jīvānanda Vidyāsāgar, adopting instead the title Vidyārṇava.

36 Taylor, Woodroffe, 98-108.

37 The most comprehensive biography is still Vasanta Kumār Pāl, Tantrācārya Śibcandra Bidyārnab (Kucbihār: Tribrttta Prakāśana, 1972), cf. Śankarnāth Rāy, Bhārater Sādhak, vol. 11 (Kolkata: Karuṇa Prakāśanī, 1958), which largely relies on it. For a recent study, see Kāŝināth Cāklādār, Mahāsādhak tantrācārya Śibcandra Bidyārṇab (Kolkata: Pustaka Bipaṇi, 2006).

38 Cāklādār, Mahāsādhak, 17. The temple is located at Baksara Borojmath.

39 Rāy, Bhārater Sādhak 11, 114. The story of Duval, a shepherd boy who rose to the rank of a famous historian, was one of several stories about European scholars and explorers that were taught at Western-oriented schools instead of those of traditional Indian heroes, saints, or divinities. Many Indians saw this as prime example of how local traditions should be replaced by Western culture. See Nandini Bhattacharya, "Anglicized-Sanskritized-Vernacularized: Translational Politics of Primer Writing in Colonial Bengal," in Language Policy and Education in India: Documents, Contexts and Debates (Oxon/New York: Routledge, 2017), 167-168.

40 Rāy, Bhārater Sādhak 11, 119. 
In his adult life, Śivacandra pursued two main goals: to reconcile Sākta and Vaișnava worship ${ }^{41}$; and second, to protect traditional culture against the influx of materialistic Western civilization. He had been a close disciple of Kāngāl Harināth (1833-1896), the famous author and Bāul singer whose disciples included several prominent artists and political or religious leaders. ${ }^{42}$ Despite his restless promulgation of "orthodoxy," Sivacandra was far from being a narrow-minded reactionary. ${ }^{43} \mathrm{He}$ emphasised that Tantric sādhan $\bar{a}$ (practice) was open to all castes and women, and he sought to create harmony between Hindus and Muslims. An active supporter of the anti-colonial Swadeshi movement, he was a strong proponent of an Indian national identity. ${ }^{44}$ He established himself as a renowned orator and enthralled an audience of thousands when he gave a thundering speech after the Partition of Bengal in 1905 (in contrast to his famous fellow orator Surendranāth Bandyopādhyāy, who spoke in English, he gave the speech in Bengali). His praise of $m \bar{a}$ as the Mother of India resonated with the popular image that had inspired Indian nationalists since Bankim Candra Chatterji's famous poem "Bande Mātaram," which was included in his famous novel Ānandamațh from 1881 and would later become the "national song" of the Republic of India. Śivacandra took part in this larger movement that strived for national and religious identity. The revival of Tantra was his chief instrument in establishing the national and religious unity he wished for, first and foremost by freeing it of misconceptions and corruptions. To this end, he founded the Sarvamangalā Sabhā that set up its headquarters in Varanasi and branched out into the whole country.

Sivacandra's two-volume Tantratattva from 1893 can be seen as a culmination of these efforts, and its English translation and dissemination by Arthur Avalon as one of the most significant successes of the guru's "anti-reformist reform." In this sometimes quite polemical yet witty work, Śivacandra mainly wanted to repel the disrespect and unbelief of the modern, Western educated Bengali class, the so-called bhadralok. He proclaimed the antiquity, greatness, purity, and authenticity of the doctrine of Tantra - the tantraśāstra - and argued that there is no conflict between Tantric, Vedic, and Puranic teachings. Moreover, he claimed that the Tantra, Vedānta, and Vaishnava śāstras all reflected the great tattva, or principle, of one "Hindu sādhanā." These arguments were backed up

\footnotetext{
41 Simply put, Vaișnavas focus on the worship of Vișnu, while Śaivas focus on Śiva. Śāktas, as part of Śaiva traditions, focus on the worship of Devī as Supreme Goddess, particularly in her manifestation as all-pervading Śakti.

42 Cāklādār, Mahāsādhak, 29-30.

43 Cf. Taylor, Woodroffe, 100.

44 Rāy, Bhārater Sādhak 11, 136-138, 66-67.
} 
by a vast body of references to traditional writings, among which those of the Kaula tradition, especially the Kulārnavatantra, stand out. ${ }^{45}$ However, it was especially the Mahānirvānatantra that Śivacandra relied on when he explained the relevance of Tantra for present-day developments, including the openness of the śāstra to all castes and both sexes.

This importance of the Mahānirvānatantra highlights the ambiguous relationship between Sivacandra's "orthodoxy" and the "Protestant reformers" who he so vehemently opposed. The text had first been published by the Ādi Brāhma Samāj, which, in the eyes of Sivacandra, embodied the corrupting Westerninfluenced "reform" more than anything else. Two of the Mahānirvānatantra's earliest manuscripts were part of the library of Rām Mohan Rāy (1772-1833), the founder of the Brāhma Samāj, whose Tantric guru Hariharānanda Bhāratī wrote the first well-known commentary to it. In contrast to traditional Tantras, the Mahānirvāṇatantra did not focus on Śiva, Śakti, or Kālī, but on an abstract, omnipresent Brahman. It emphasized that the Tantric sādhanā was the appropriate one for the present Kali Yuga. As Hugh Urban has highlighted, its modern, reformist aspects were especially attractive because of their claim to represent ancient wisdom that had been handed down in secret throughout the ages and was now revealed to meet the needs of the modern age. ${ }^{46}$ The disciples of the Brāhma Samāj, Śivacandra, and many other intellectuals took place in controversial debates about the meaning of these revelations, trying to renegotiate the meaning of Tantra an its role for Indian society. In Śivacandra's eyes, the Brāhma Samāj was a prime example of how the proper understanding of Tantra had been lost due to the influence of Christian teachings, which had led its members astray. In the 1890s, he became widely renowned for a traditionalist yet reformist perspective that claimed the tantraśāstra's superiority over the Western education that threatened to replace Indian tradition in the same way that Duval had been supposed to replace Kṛ̣̣na.

45 Kaula practices were compiled and integrated into a complex ritual and philosophical system between the eighth and eleventh centuries. Kashmir emerged as a centre of this systematisation, with Abhinavagupta (ca. 960-1020) as its most famed and influential proponent. Kashmiri Śaivism, as it was represented in works such as Abhinavagupta's Tantrāloka, was nondualistic and developed a highly complex philosophical reflection on śakti. See, e.g., Alexis Sanderson, "Śaivism and the Tantric Traditions," in The World's Religions, ed. Stewart Sutherland, et al. (London: Routledge and Kegan Paul, 1988) or Paul Eduardo Muller-Ortega, The Triadic Heart of Siva: Kaula Tantricism of Abhinavagupta in the Non-dual Saivism of Kashmir (Albany: State University of New York Press, 1989).

46 Urban, Tantra, 70. 


\section{Tantra as Experimental Science}

One of the central arguments that Sivacandra levelled against the critics of Tantra, and by extension against the corruptions of Western education, is the "practical," "scientific," and "experiential" character of Tantric sādhanā. Time and again, his Tantratattva emphasises that it is not blind faith that binds the Tantric practitioner to his sādhanā, but the experience of actual, tangible results. In their introductions and commentaries, Arthur Avalon repeatedly stressed this aspect. In the Introduction to volume one, we read: "For the understanding of the Tantrik, or, indeed, any other beliefs and practices, the usual dry-as-dust investigation of the savant is insufficient. In the first place a call should be made upon actual present experience." ${ }^{47}$ This argument is extended to the valuation of religion in general - that is, religion in its orthodox form, free from reformist corruption:

It is Sadhana which alone in any system, whether Hindu or otherwise, is really fruitful. The Tantra claims to be practical [. . .] in that it affords the direct proof of experience. [. . .] The Tantra further claims not only to be practical and to contain provisions available for all without distinction of caste or sex, but also to be fundamentally rational. ${ }^{48}$

This argument is not only based on the authority of scriptural and oral tradition, but also on the claim that many Indian concepts conform to the results of the most recent scientific and psychological research and metaphysical speculation . . ."49 The practice of "Tantrik Yoga," for instance, should be regarded as "a ritual which is at the same time, when rightly understood, singularly rational and psychologically profound." With reference to a review from The Quest of October 1913, it is maintained that Tantric ritual was "perhaps the most elaborate system of auto-suggestion in the world." ${ }^{50}$ This was one of Woodroffe's/Avalon's favourite comparisons among many others, scattered across their numerous writings whose later editions often saw chaotic modifications and expansions. For instance, Woodroffe gave a range of lectures that were later turned into chapters of Shakti and Shakti, some of which were first delivered to the Vivekananda Society in 1917-1918 and to the Dacca Literary Society in 1916, which was then printed in The Theosophist of October 1918.

The most systematic comparison between tantraśāstra and Western scientific and philosophical concepts can be found in the World as Power series,

47 Woodroffe, Principles of Tantra 1, xiii-xiv.

48 Woodroffe, Principles of Tantra 1, lxxii.

49 Woodroffe, Principles of Tantra 1, 2: vii-viii.

50 Woodroffe, Principles of Tantra 1, 1: xvi. 
published under Woodroffe's name from 1922 until 1929. ${ }^{51}$ Woodroffe acknowledged that the World as Power series was significantly indebted to Pramathanāth Mukhopādhyāy (1881-1973, later Swāmī Pratyagātmānanda Saraswatī). Mukhopādhyāy was one of Woodroffe's main collaborators and a major provider of ideas. ${ }^{52}$ He had received an education in philosophy and started his career as a professor at the National Council of Education, which was founded as a nationalist initiative in 1906 as a result of the Swadeshi movement. ${ }^{53}$ The Tantric doctrine of Sivacandra was rearticulated by Mukhopādhyāy in the light of Western ideas, especially German Idealism. ${ }^{54}$ Śivacandra's Śākta non-dualist interpretation of Advaita Vedānta, which focused on the all-pervading śakti, was identified by him with Western Monism - a notion that would be essential to the writings of Woodroffe/Avalon. In some ways, this paralleled the ideas of Vivekānanda the essential difference being an affirmative application of Tantric Kaula Śākta teachings revolving around śakti as the reconciliation of opposites such as mind and matter, individual and divine consciousness, or transcendent and empirical experience. As Woodroffe maintained in Shakti and Shakta, the Monism of Ernst Haeckel pointed out "in conformity with Shakta Advaitavada that Spirit and Matter are not two distinct entities but two forms or aspects of one single Entity or fundamental Substance." 55 This mirrored ideas that his friend Mukhopādhyāy had previously expressed in his books Approaches to Truth (1914) and The Patent Wonder (1915), which are among the most cited by Woodroffe.

Mukhopādhyāy, who deserves a comprehensive study of its own, introduced a fascinating synthesis of contemporary Western and Indian philosophical thought to the writings of Woodroffe/Avalon and decisively coined the understanding of Sākta tantraśāstra that we find therein. In The World as Power, it is maintained that consciousness was "wider and deeper than cerebral

51 The parts are Reality (1922), Power as Life (1922), Power as Mind (1922), Power as Matter (1923), Causality and Continuity (1923), and Mahāmāyā: Power as Consciousness (1929). See Taylor, Woodroffe, 192-202.

52 His importance for Woodroffe/Avalon was, e.g. in Rāy, Bhārater Sādhak 11, 174. The reader can easily tell apart the clearly structured and well-argued passages by Mukhopādhyāy in The World as Power from the more confused ones from the pen of Woodroffe.

53 At that time, he was a colleague of Śrī Arabinda (Aurobindo) and maintained contacts with him. See Pratyagātmānanda Saraswatī, Collected Works, vol. 1 (Kolkata: Saraban Asran, 1980), 7. 54 Andrew Sartori, "Beyond Culture-Contact and Colonial Dicourse: 'Germanism' in Colinial Bengal,” Modern Intellectual History 4, no. 1 (2007): 86-89.

55 Woodroffe, Shakti and Shakta, 272. 
consciousness," and that the "Cartesian dualism of Mind and Matter (with no possibility of interaction) is commonly discarded in Modern Psychology which tends more and more to regard them not as merely 'parallel aspects' but as coessential." ${ }^{26}$ With reference to authors such as William James, Thomas Henry Huxley, or Émile Boirac, we learn that the "New Psychology" in the West "is establishing mind as a force, capable of energising in uncommon ways, and hence ushering in the philosophy and practice of so called 'occult powers' and Yoga."57 The Vitalism of Henri Bergson, it is maintained, leads directly to the ancient truths of the Sākta doctrine. Especially noteworthy are the references to William James, for instance when we read that it "may be that the so-called subconsciousness is really cosmic consciousness," which is what the philosophy of Vedānta had always taught: "In India, the Vedāntic doctrine has afforded a wide and firm basis for the understanding of our common as well as 'occult' experiences, and that doctrine is clear in its main outlines." 58 The Sākta doctrine presented by Mukhopādhyāy and Woodroffe claimed to be thoroughly rational and scientific, but it was also decidedly worldaffirming in its focus of the notion of Power/śakti, not only on an abstract philosophical level, but as the psycho-physical cultivation of the individual Self (ätman) through Tantric ritual. ${ }^{59}$

As has become clear by now, Woodroffe and his Indian collaborators extensively referred to the fields of occultism, psychical research, psychology, physiology, Idealism, Monism, Vitalism, and other Western currents to argue for the scientific value of Tantra. They explicitly regarded Tantra as the essence of "Indian occultism" and the popularity of Western occultism as an expression of the tendency to rediscover an ancient orthodoxy. In this light, fascinating parallels between Indian reformers and Western esotericists become tangible: their exchange was largely based on a shared language of esotericism and comparisons between Western esoteric concepts and Indian teachings. In both cases, the rejection of modern materialism, scepticism, and atheism were a key component in the defence of orthodoxy or "tradition."

56 John Woodroffe, The World as Power. Power as Mind (Madras: Ganesh \& Co., 1922), xi, xiv. 57 Woodroffe, The World as Power, xv-xvi.

58 John Woodroffe and Pramathanāth Mukhopādhyāy, Mahāmāyā: The World as Power: Power as Consciousness (Madras: Ganesh \& Co., 1929), 186, 188.

59 This notion was especially attractive for Western occultists, most notoriously Julius Evola. 


\section{Tantra as Esoteric Tradition}

Neither Woodroffe nor his Indian friends regarded the revival of Tantra as an exclusively Indian affair. Tantra was depicted as the esoteric core of a religious tradition that formed the foundation of other "orthodoxies" as well. As has been seen, the language of "Indian occultism" or "Tantrik occultism" was frequently used to refer to a universal orthodoxy shared by Western and Indian tradition. In Shakti and Shakta, Woodroffe emphasised the scientific and psychological values of its practice by a discussion of magic, which was, according to him, "common to all early religions":

Magic was dismissed by practically all educated men as something too evidently foolish and nonsensical to deserve attention or inquiry. In recent years the position has been reversed in the West, and complaint is again made of the revival of witchcraft and occultism to-day. The reason of this is that modern scientific investigation has established the objectivity of some leading phenomena of occultism. ${ }^{60}$

Again, Woodroffe maintained that current scientific observations were confirming ancient doctrines; and again, he stressed that these doctrines had always thrived in India, while they had been dismissed and forgotten in the West. Woodroffe's approach to magic is interesting, not only because it reflects contemporary theories about magic as the origin of religion, but also because of his reference to theories of magic as will-power that were wide-spread in Western esoteric contexts. Similar to Majumdār's discussion of the occult sciences, he explained magic as a "Power of Thought" and stressed that "Thought is a Force" that can be cultivated and exploited by the magician.

Apart from this "scientific" explanation of magic and occultism, Woodroffe also advanced an historical argument by declaring: "It has been well observed that there are two significant facts about occultism, namely its catholicity (it is to be found in all lands and ages) and its amazing power of recuperation after it has been supposed to have been disproved as mere 'superstition'." 61 Here, "catholicity" is clearly meant to denote the universal character of occultism. But, as has been indicated above, Woodroffe also drew parallels between Indian orthodoxy and the actual Catholicism of the Church, which he located on the same side as Tantra in the struggle against the corruptions of modernity

60 Woodroffe, Shakti and Shakta, 88.

61 Woodroffe, Shakti and Shakta, 91. 
and its "Protestant” reformism. Śivacandra's Tantratattva was explicitly framed in such a way:

The same forces, however, against which this book, as also other orthodoxies, protest, are in conflict both with Hinduism in its present Tantrik form and with Christianity of the older type. In the present mingling of East and West, each is providing a ferment for the other [. . .].

In fact, in parts the book reads like an orthodox Catholic protest against "modernism," and is thus interesting as showing how many fundamental principles are common to all orthodox forms of belief, whether of West of East. ${ }^{62}$

Throughout his writings, Woodroffe emphasised the similarities, and indeed the shared roots, of both Tantra and Catholicism. This does not only concern their historical dimension but also their practical modes of worship, which had been denounced by "Protestantism" and reformism as superstition and idolatry. ${ }^{63}$ The same argument was also taken up by Pramathanāth Mukhopādhyāy:

Thus, amongst Christians, the Catholic Church prescribes a full and powerful Sādhanā in its sacraments (Saṁskāra) and Worship (Pūjā, Upāsanā), Meditation (Dhyāna), Rosary (Japa) and the like. But any system to be fruitful must experiment to gain experience. The significance of the Tantra Shāstra lies in this that it claims to afford a means available to all, of whatever caste and of either sex, whereby the truths taught may be practically realized. ${ }^{64}$

These passages demonstrate the link between the claim for the scientific, rational, and experimental character of Tantric religious practice and between the historical dimension of the underlying universal religious, "orthodox" tradition. On the one hand, this formed a structural analogy to the discourses of Western esotericism; an analogy that had itself been the outcome of an exchange between Western and Indian thinkers and practitioners in the nineteenth century. On the other hand, these discussions entered the field of the academic theory and history of religion, exerting a lasting influence on the study of Indian religious history.

62 Woodroffe, Principles of Tantra 1, xiii, xvi.

63 E.g., ibid., lxxi; Woodroffe, Shakti and Shakta, 106. In the latter reference, we find a rebuttal of an article by Moriz Winternitz in the Ostasiatische Zeitschrift from 1916, which likened sādhanā to magic. Woodroffe concluded that the "mind which takes these views is like that of the Protestant who called the Catholic Mass 'Hocus Pocus'," and that the "learned Professor has also evidently no liking for 'Occultism' and 'India-faddists' (Indiensschwarmern). But the former exists whether we like its facts or not."

64 Woodroffe, Shakti and Shakta, 61-62. Original emphasis. 


\section{Tantra and the Comparative Study of Religions}

As the preceding section has shown, the historical dimension of the tantraśāstra of Woodroffe and his Indian collaborators was determined by a religious traditionalism that would inspire academic scholars of religion well into the second half of the twentieth century. These included authors such as Sylvain Lévi, Paul Masson-Oursel, Walter Evans-Wentz, Heinrich Zimmer, Mircea Eliade, Carl Gustav Jung, Lilian Silburn, or Agehananda Bharati. As diverse as these authors were, they heavily relied on the Woodroffe/Avalon writings and continued his approach to Tantra in a similar vein. ${ }^{65}$ The result was, in the words of Hugh Urban, a veritable "Tantrocentrism" at the heart of the history of religion. ${ }^{66}$ Much of this interest in Tantra was due to what Jeffrey Kripal called the "countercultural echoes of contemporary Tantric Studies," 67 an aspect that leads us to the second large group of recipients: esotericists. Beginning with the exchange within the pages of The Theosophist that has been the starting point of this article, Theosophists and other esotericists rapidly became fascinated with the topic of Tantra, and especially with its Yogic aspects. Later esotericists such as Julius Evola, Israel Regardie, Gerald J. Yorke, or Kenneth Grant heavily relied on Woodroffe's/Avalon's work and, in the case of Evola, corresponded with him. ${ }^{68}$ Notions such as "Left-Hand Path" (i.e., vāmācara) Tantra or a "Yoga of Power" are omnipresent in occultist contexts ever since. ${ }^{69}$ The Eranos meetings exemplify that the borders between these esoteric and academic contexts were not

65 Jeffrey J. Kripal, Kali's Child: The Mystical and the Erotic in the Life and Teachings of Ramakrishna (Chicago: University of Chicago Press, 1995), 28.

66 Urban, Tantra, 165.

67 Jeffrey J. Kripal, "Remembering Ourselves: On Some Countercultural Echoes of Contemporary Tantric Studies," Religions of South Asia 1, no. 1 (2007).

68 See, e.g., the reference in John Woodroffe, Is India Civilized? Essays on Indian Culture (Madras: Ganesh \& Co., 1918), vi, were an article by Evola in Il Nuovo Paese is quoted, according to which the Tantric system "offers many suggestions to the West in virtue of its accentuation of Will and Power.” Cf. Woodroffe, Shakti and Shakta, 434.

69 Hugh B. Urban, Magia Sexualis: Sex, Magic, and Liberation in Modern Western Esotericism (Berkeley: University of California Press, 2006), 140-161; Henrik Bogdan, "Challenging the Morals of Western Society: The Use of Ritualized Sex in Contemporary Occultism," The Pomegranate 8, no. 2 (2006); Gordan Djurdjevic, "The Great Beast as a Tantric Hero: The Role of Yoga and Tantra in Aleister Crowley's Magick,” in Aleister Crowley and Western Esotericism, ed. Henrik Bogdan and Martin P. Starr (Oxford/New York: Oxford University Press, 2012); Kennet Granholm, "The Serpent Rises in the West: Positive Orientalism and Reinterpretation of Tantra in the Western Left-Hand Path," in Transformations and Transfer of Tantra in Asia and Beyond, ed. István Keul, Religion and Society (Berlin: De Gruyter, 2012). 
only very fluid, but often non-existent. ${ }^{70}$ There, scholars such as Eliade, Jung, or Jakob Wilhelm Hauer discussed the topics of Tantra and Yoga and further developed ideas that had emerged in the very context that has been the subject of this article. $^{71}$

Of course, Woodroffe was not the only example of a Westerner that engaged with learned Indians. Evans-Wentz is another prominent example with close ties to the Theosophical Society, who also befriended Woodroffe and collaborated with him. ${ }^{72}$ Ananda Coomaraswamy, of Ceylonese descent but raised in England, is especially worth mentioning in the present context because of his relevance for Traditionalism and his involvement with the milieu around Woodroffe. ${ }^{73}$ Indeed, there are rumours that Coomaraswamy had received direct support from Śivacandra, whom he reportedly met in Woodroffe's house together with the art historian Ernest Binfield Havell. ${ }^{74}$ The claim of Sivacandra's influence on him still awaits clarification, but it appears to be evident that Coomaraswamy frequented the same circles as Woodroffe. ${ }^{75}$ In any case, we do find in Coomaraswamy's writings the idea of a universal mysticism that is expressed in the "Tantric Doctrine" as well as in those of Thomas Aquinas and Meister Eckhart. ${ }^{76}$

Among those scholars who were immediately influenced by such traditionalist and perennialist conceptions, Eliade is certainly and outstanding example. Not surprisingly, he focused on the aspects of sādhanā and Yoga, confirming and further elucidating the aspects that had been highlighted by Woodroffe/ Avalon. ${ }^{77}$ These included the world-affirming and "anti-speculative" attitude of Tantra, but also the "six-plus-one" chakra system that had been established as the standard thanks for the Woodroffe/Avalon books. ${ }^{78}$ It is of special interest to observe that these ideas were linked by Eliade to a universal "occultism"

70 Hans Thomas Hakl, Eranos: An Alternative Intellectual History of the Twentieth Century (Abingdon: Routledge, 2013).

71 E.g. the respective aspects in Urban, Tantra, 165-202; cf. Hugh B. Urban, The Power of Tantra: Religion, Sexuality, and the Politics of South Asian Studies (London: I.B. Tauris, 2010).

72 Woodroffe wrote a foreword to his famous Tibetan Book of the Dead (1927).

73 Mark Sedgwick, Against the Modern World: Traditionalism and the Secret Intellectual History of the Twentieth Century (Oxford: Oxford University Press, 2004), 34-36, 51-53.

74 Pāl, Tantrācārya, 105-106; Rāy, Bhārater Sādhak 11, 175-176.

75 Taylor, Woodroffe, 67, 104-105.

76 Ananda Coomaraswamy, "The Tantric Doctrine of Divine Beauty," Annals of the Bhandarkar Oriental Research Institute 19, no. 2 (1938).

77 Mircea Eliade, Yoga: Immortality and Freedom (New York: Pantheon Books, 1958), 200-273. 78 Eliade, Yoga, 241-243. Cf. White, Kiss, 220-229; Taylor, Woodroffe, 171; Gavin D. Flood, The Tantric Body: The Secret Tradition of Hindu Religion (London/New York: I.B. Tauris, 2006), 158. 
whose ancient roots were burgeoning again in modern times. In his study of Occultism from 1976, he wrote:

. . .contemporary scholarship has disclosed the consistent religious meaning and the cultural function of a great number of occult practices, beliefs, and theories, recorded in many civilizations, European and non-European alike, and at all levels of culture, from folk rituals-such as magic and witchcraft-to the most learned and elaborate secret techniques and esoteric speculations: alchemy, Yoga, Tantrism, Gnosticism, Renaissance Hermeticism, and secret societies and Masonic lodges of the Enlightenment period. ${ }^{79}$

This exemplifies how a contemporary reader of academic and esoteric works about Tantra would encounter very similar ideas about its universalistic application, reflected by a traditionalist or perennialist historiography and phenomenology. The same can be said about the practice of Tantra and its parallels, if not identity, with Western scientific concepts. For instance, in the 1970s, the occultist author Israel Regardie took up Woodroffe's/Avalon's discussion, mainly through the œuvre of Jung, of Tantra and Yoga as psychological systems of magical self-cultivation. In his The Middle Pillar of 1970, Regardie declared that the "psychologies of the past may be summarised by the use of the words Yoga and Magic." Their common techniques were based on a non-dualist ontology:

Analytical Psychology and Magic comprise in my estimation two halves or aspects of a single technical system. Just as the body and mind are not two separate units, but are simply the dual manifestations of an interior dynamic "something" so psychology and Magic comprise similarly a single system whose goal is the integration of the human personality. ${ }^{80}$

This concern for the modern adaption of ancient theories and practices - and their identification with "occultism" of "magic" - has been a recurring theme within the sources that were discussed by now. The assumption that they grew out of a primordial religious tradition was especially espoused by esotericists in the decades around 1900, but it was also adopted by renowned academic scholars who approached the study of religion through a perennialist or phenomenological perspective.

This is not to say that there were no differences between academic and esoteric approaches to Tantra, or to Indian religious history in general. The point is that both orientalist studies and the dazzling sphere of esotericism were highly

79 Mircea Eliade, Occultism, Witchcraft, and Cultural Fashions: Essays in Comparative Religions (Chicago: University of Chicago Press, 1976), 58.

80 Israel Regardie, The Middle Pillar: A Co-Relation of the Principles of Analytical Psychology and the Elementary Techniques of Magic (Saint Paul: Llewellyn Publications, 1970), 15-16. 
heterogeneous fields that shared interests, methodologies, organisations, and individual protagonists. Both developed against the background of late eighteenth-century debates about the origin of religion and the ground-breaking philological discoveries that enabled them. Both increasingly turned to the "Light of the East," recognising the antiquity of the language and concepts that they apparently shared with "Western" traditions. And both, in different fashions, debated the demarcations between religion, science, and philosophy. Towards the end of the nineteenth century, the Theosophists became one of the most active forces behind the study of Indian traditions, producing countless translations, editions, and studies, many of which are still being used today. Moreover, they provided learned Indians with a platform to communicate with a vast readership, thus contributing to the emancipation of subaltern voices that had not been able to use such channels before. ${ }^{81}$ The reformist thrust and commitment to educational and national sovereignty that was expressed by many Theosophists contributed to this. A clearly visible result of this was the profound transformation of Theosophical ideas by Indians, a process that deserves further attention in future research. ${ }^{82}$ As the writings of Woodroffe/ Avalon exemplify, a look at the underlying exchanges reveals a complex tangle that can only be fully comprehended from a global perspective. In the present context, these exchanges mainly concern the relationship between religion and science, and it were Theosophists and other esotericists who most vocally represented the attempt to cross the boundaries between them. ${ }^{83}$

This was one of several structural analogies, themselves the outcome of exchanges since the early nineteenth century, between "Western esoteric" and Indian reformist (or "orthodox") contexts. Tantra would emerge as a central identity marker in this discourse, and it was largely thanks to the Indian pandits and their ally Woodroffe that it became recognised as a major subject of serious research. In Shakti and Shakta, Woodroffe himself acknowledged this

81 This was not without ambivalences, as Orientalist notions were part and parcel of Theosophical approaches to "India," which, after all, took place within a colonial context. For a discussion, see, e.g., Viswanathan, Outside the Fold, 177-207; Gauri Viswanathan, "The Ordinary Business of Occultism,” Critical Inquiry 27, no. 1 (2000).

82 See the recent volume Theosophy Across Boundaries: Transcultural and Interdisciplinary Perspectives on a Modern Esoteric Movement, edited by Hans Martin Krämer and Julian Strube (Albany: State University of New York Press, 2020). Also see the contributions to Julie Chajes and Boaz Huss, eds., Theosophical Appropriations: Esotericism, Kabbalah, and the Transformation of Traditions, The Goldstein-Goren Library of Jewish Thought (Beer Sheva: Ben-Gurion University of the Negev Press, 2016).

83 Michael Bergunder, “'Religion' and 'Science’ Within a Global Religious History,” Aries 16, no. 1 (2016). 
ongoing change in scholarly attitude. After his severe attacks on the ignorance of "the Orientalist and Missionary," he could observe how some orientalists came to appreciate the values of Tantra:

As M. Masson-Oursel so well puts it (Esquisse d'une histoire de la philosophie indienne, p. 257) 'Dans le tantrisme triomphent une conception immanentiste de l'intelligibilité, l'esprit s'assigne pour but, non de se laisser vivre mais de se créer une vie digne de lui, une existence omnisciente omnipotente, qu'il maitrisera parce qu'il en sera auteur' (by Sādhanā). ${ }^{84}$

A look at Masson-Oursel's study shows that his understanding of Tantra was informed by none other than the writings of Arthur Avalon and Woodroffe. ${ }^{85}$ Effectively, Woodroffe was thus citing himself, providing an impressive example of his growing influence on how the learned world viewed the tantraśāstra. This influence was the outcome of the efforts of a British judge as much as those of a Bengali guru, his learned disciples, and the Western esotericists they first reached out to in order to praise the value of a profound philosophical and scientific tradition that should revive the ancient greatness of India.

\section{Bibliography}

Baier, Karl. Meditation und Moderne: Zur Genese eines Kernbereichs moderner Spiritualität in der Wechselwirkung zwischen Westeuropa, Nordamerika und Asien. 2 vols. Vol. 1, Würzburg: Königshausen \& Neumann, 2009.

_- "Mesmeric Yoga and the Development of Meditation within the Theosophical Society." Theosophical History 16, no. 3-4 (2012): 151-161.

—. "Theosophical Orientalism and the Structures of Intercultural Transfer: Annotations on the Appropriation of the Cakras in Early Theosophy." In Theosophical Appropriations: Esotericism, Kabbalah, and the Transformation of Traditions, edited by Julie Chajes and Boaz Huss, 309-354. Beer Sheva: Ben-Gurion University of the Negev Press, 2016.

84 Woodroffe, Shakti and Shakta, 325: “As M. Masson-Oursel so well puts it (Esquisse dune histoire de la philosophie indienne, p. 257) 'In tantrism, an immanentist conception of intelligibility triumphs, the spirit sets as its goal, not to live passively but to create a dignified live by itself, an omniscient, omnipotent existence, which it will master because it will be its author' (by Sādhanā)."

85 Paul Masson-Oursel, Esquisse d'une histoire de la philosophie indienne (Paris: Paul Geuthner, 1923), 232, 82. Listed are, "among the numerous publications" Avalon and Woodroffe, The Serpent Power, Shakti and Shakta, Tantrik Texts, Principles of Tantra, The Great Liberation, Anandalahari, Mahimnastava, Hymns to the Goddess, and the volumes Reality and Power as Life of The World as Power. 
Banerji, Sures Chandra. Tantra in Bengal: A Study in its Origin, Development, and Influence. 2nd ed. New Delhi: Manohar Publications, 1992.

Bergunder, Michael. "Experiments with Theosophical Truth: Gandhi, Esotericism, and Global Religious History." Journal of the American Academy of Religion 82 (2014): 398-426.

__. "'Religion' and 'Science' Within a Global Religious History.” Aries 16, no. 1 (2016): 86-141.

Bevir, Mark. "In Opposition to the Raj.” History of Political Thought 19 (1998): 61-77.

_ . "Theosophy and the Origins of the Indian National Congress." International Journal for Hindu Studies 7, no. 1/3 (2003): 99-115.

_ . "Theosophy as a Political Movement." In Gurus and Their Followers, edited by Antony Copley. Delhi: Oxford University Press, 2000.

Bhattacharya, Nandini. "Anglicized-Sanskritized-Vernacularized: Translational Politics of Primer Writing in Colonial Bengal." In Language Policy and Education in India:

Documents, Contexts and Debates, 166-183. Oxon/New York: Routledge, 2017.

Bogdan, Henrik. "Challenging the Morals of Western Society: The Use of Ritualized Sex in Contemporary Occultism." The Pomegranate 8, no. 2 (2006): 211-246.

Cāklādār, Kāśīnāth. Mahāsādhak tantrācārya Śibcandra Bidyārṇab. Kolkata: Pustaka Bipaṇi, 2006.

Chajes, Julie, and Boaz Huss, eds. Theosophical Appropriations: Esotericism, Kabbalah, and the Transformation of Traditions. The Goldstein-Goren Library of Jewish Thought, vol. 21. Beer Sheva: Ben-Gurion University of the Negev Press, 2016.

Chakravarti, Chintaharan. Tantras: Studies on their Religion and Literature. Calcutta: Punthi Pustak, 1963.

Coomaraswamy, Ananda. "The Tantric Doctrine of Divine Beauty." Annals of the Bhandarkar Oriental Research Institute 19, no. 2 (1938): 173-183.

Derrett, John D.M. “A Juridical Fabrication of Early British India: The Mahānirvāṇa-Tantra.” Zeitschrift für Rechtswissenschaft 69, no. 2 (1968): 138-181.

Djurdjevic, Gordan. "The Great Beast as a Tantric Hero: The Role of Yoga and Tantra in Aleister Crowley's Magick." In Aleister Crowley and Western Esotericism, edited by Henrik Bogdan and Martin P. Starr, 107-140. Oxford/New York: Oxford University Press, 2012.

Eliade, Mircea. Occultism, Witchcraft, and Cultural Fashion: Essays in Comparative Religions. [in eng] Chicago: University of Chicago Press, 1976.

- Yoga: Immortality and Freedom. New York: Pantheon Books, 1958.

Flood, Gavin D. The Tantric Body: The Secret Tradition of Hindu Religion. London/New York: I.B. Tauris, 2006.

Goudriaan, Teun, and Sanjukta Gupta. Hindu Tantric and Sākta Literature. Wiesbaden: Harrassowitz, 1981.

Granholm, Kennet. "The Serpent Rises in the West: Positive Orientalism and Reinterpretation of Tantra in the Western Left-Hand Path." In Transformations and Transfer of Tantra in Asia and Beyond, edited by István Keul. Religion and Society, 495-519. Berlin/Boston: De Gruyter, 2012.

Gupta, Sanjukta, Dirk Jan Hoens, and Teun Goudriaan. Hindu Tantrism. Leiden: Brill, 1979.

Hakl, Hans Thomas. Eranos: An Alternative Intellectual History of the Twentieth Century. Abingdon/New York: Routledge, 2013.

Kripal, Jeffrey J. Kali's Child: The Mystical and the Erotic in the Life and Teachings of Ramakrishna. Chicago: University of Chicago Press, 1995. 
—_. "Remembering Ourselves: On Some Countercultural Echoes of Contemporary Tantric Studies." Religions of South Asia 1, no. 1 (2007): 11-28.

Lubelsky, Isaac. Celestial India: Madame Blavatsky and the Birth of Indian Nationalism. Sheffield/Oakville: Equinox, 2012.

Majumdār, Baradā Kānta. "A Glimpse of Tantrik Occultism 1.” The Theosophist 1, no. 10 (1880): 244-245.

—. "The Occult Sciences." In A Guide to Theosophy, edited by Tukaram Tatya, 205-209. Bombay: The Bombay Theosophical Publication Fund, 1887.

—. "Tantric Philosophy." The Theosophist 1, no. 7 (1880): 173-174.

Masson-Oursel, Paul. Esquisse d'une histoire de la philosophie indienne. Paris: Paul Geuthner, 1923.

Muller-Ortega, Paul Eduardo. The Triadic Heart of Śiva: Kaula Tantricism of Abhinavagupta in the Non-dual Śaivism of Kashmir. Albany: State University of New York Press, 1989.

Padoux, André. The Hindu Tantric World: An Overview. Chicago/London: University of Chicago Press, 2017.

Pāl, Vasanta Kumār. Tantrācārya Śibcandra Bidyārnab. Kucbihār: Tribṛtta Prakāśana, 1972.

Rāy, Śankarnāth. Bhārater Sādhak. Vol. 11, Kolkata: Karuṇā Prakāśanī, 1958.

Regardie, Israel. The Middle Pillar: A Co-Relation of the Principles of Analytical Psychology and the Elementary Techniques of Magic. Saint Paul: Llewellyn Publications, 1970.

Sanderson, Alexis. "Meaning in Tantric Ritual." In Essais sur le Rituel III: Colloque du Centenaire de la Section des Sciences religieuses de l'École Pratique des Hautes Études, edited by Anne-Marie Blondeau and Kristofer Schipper, 15-95. Louvain-Paris: Peeters, 1995.

_. "Śaivism and the Tantric Traditions." In The World's Religions, edited by Stewart Sutherland, Leslie Houlden, Peter Clarke and Friedhelm Hardy, 660-704. London: Routledge and Kegan Paul, 1988.

Saraswatī, Pratyagātmānanda. Collected Works. Vol. 1, Kolkata: Saraban Asran, 1980.

Sartori, Andrew. "Beyond Culture-Contact and Colonial Dicourse: 'Germanism' in Colinial Bengal.” Modern Intellectual History 4, no. 1 (2007): 77-93.

Sedgwick, Mark. Against the Modern World: Traditionalism and the Secret Intellectual History of the Twentieth Century. Oxford/New York: Oxford University Press, 2004.

Strube, Julian. Sozialismus, Katholizismus und Okkultismus im Frankreich des 19. Jahrhunderts: Die Genealogie der Schriften von Eliphas Lévi. Religionsgeschichtliche Versuche und Vorarbeiten. Berlin/Boston: De Gruyter, 2016.

Taylor, Kathleen. Sir John Woodroffe, Tantra and Bengal: An Indian Soul in a European Body? Richmond: Curzon, 2001.

Truth Seeker. "Yoga Philosophy." The Theosophist 1, no. 4 (1880): 86-87.

Urban, Hugh B. Magia Sexualis: Sex, Magic, and Liberation in Modern Western Esotericism. Berkeley: University of California Press, 2006.

- The Power of Tantra: Religion, Sexuality, and the Politics of South Asian Studies. London/New York: I.B. Tauris, 2010.

- Tantra: Sex, Secrecy Politics, and Power in the Study of Religions. Berkeley: University of California Press, 2003.

Veer, Peter van der. Imperial Encounters: Religion and Modernity in India and Britain. Princeton: Princeton University Press, 2001.

Viswanathan, Gauri. “The Ordinary Business of Occultism.” Critical Inquiry 27, no. 1 (2000): 1-20. 
- Outside the Fold: Conversion, Modernity, and Belief. Princeton: Princeton University Press, 1998.

Wessinger, Catherine L. Annie Besant and Progressive Messianism. Studies in Women and Religion. Lewiston: Mellen, 1988.

White, David Gordon. “Introduction." In Tantra in Practice, edited by David Gordon White, 3-38. Princeton/Oxford: Princeton University Press, 2000.

- Kiss of the Yogini: 'Tantric Sex' in its South Asian Contexts. Chicago/London: University of Chicago Press, 2003.

Woodroffe, John. Is India Civilized? Essays on Indian Culture. Madras: Ganesh \& Co., 1918.

-. Principles of Tantra. Vol. 1, London: Luzac \& Co., 1914. . Principles of Tantra. Vol. 2, London: Luzac \& Co., 1914.

- The Serpent Power: Being the Shat-Chakra-Nirupana and Paduka-Panchaka. Madras: Ganseh \& Co., 1924.

- Shakti and Shakta: Essays and Addresses on the Shakta Tantrashastra. London: Luzac \& Co., 1918.

- Shakti and Shakta: Essays and Addresses on the Shakta Tantrashastra. 3rd ed. Madras/London: Ganesh \& Co./Luzac \& Co., 1929.

- The World as Power: Power as Life. Madras: Ganesh \& Co., 1922.

- The World as Power: Power as Mind. Madras: Ganesh \& Co., 1922.

- Woodroffe, John and Pramathanāth Mukhopādhyāy. Mahāmāyā: The World as Power. Power as Consciousness. Madras: Ganesh \& Co., 1929. 